\title{
Mapping of the Matic Data of Kinnerasani Basin using GIS and RS for Management of Land Resources
}

\author{
G. Kishore Kumar ${ }^{1}$, A. Mani ${ }^{1}$, G. Manojkumar ${ }^{2}$ and K. Sadasiva Rao ${ }^{3}$ \\ ${ }^{1}$ College of Agricultural Engineering, ANGRAU, Bapatla, India \\ ${ }^{2}$ College of Agricultural Engineering, PJTSAU, Sangareddy, India \\ ${ }^{3}$ Agricultural Engineering and Technology, PJTSAU, Hyderabad, India \\ *Corresponding author
}

\begin{tabular}{|c|c|}
\hline & A B S T R A C T \\
\hline & Thematic maps present information relating to spatial variations in the distribution of \\
\hline Keywords & $\begin{array}{l}\text { specific geographical features at a regional scale or across the entire basin. The spatial } \\
\text { distribution of thematic maps aids in decision-making of management of resources. }\end{array}$ \\
\hline $\begin{array}{l}\text { LULC, DEM, } \\
\text { Cartosat, LISS }\end{array}$ & $\begin{array}{l}\text { Different thematic maps generated for the Kinnerasani basin include watershed boundary, } \\
\text { drainage network, slope map, landuse/landcover map and soil map with the help of Survey }\end{array}$ \\
\hline Article Info & $\begin{array}{l}\text { of India topographical map and Cartosat DEM. LULC map was developed using IRS P6 } \\
\text { LISS III satellite data. Deciduous forest is the major land use with } 64 \% \text { followed by crop }\end{array}$ \\
\hline $\begin{array}{l}\text { Accepted: } \\
\text { 24 November } 2018 \\
\text { Available Online: } \\
10 \text { December } 2018\end{array}$ & $\begin{array}{l}\text { land with } 25 \% \text { of the area of Kinnerasani basin. Water bodies are occupying an area of } 3 \% \\
\text { followed by fallow land }(2 \%) \text {. The basin consists of mainly two types of soils. Majority of } \\
\text { the area is under Clay soils with } 84 \text { percent and Clay loam soil occupies } 14 \text { percent and } \\
\text { remaining } 2 \text { percent is under rock and water bodies. Soil depth and productivity maps were } \\
\text { also generated for sustainable land management. }\end{array}$ \\
\hline
\end{tabular}

\section{Introduction}

A thematic map indicates the spatial distribution of one or more specific data themes for selected geographic areas. The map may be qualitative or quantitative in nature. Thematic maps can be used for exploratory spatial data analysis, confirming hypotheses, synthesizing spatial data by revealing patterns and relationships, and data presentation. The maps serve three primary purposes. First, they provide specific information about particular locations. Second, they provide general information about spatial patterns. Third, they can be used to compare patterns on two or more maps. It is used in research, statistic, geography and many other fields. In case of GIS, many characteristics of geography are represented by thematic map.

Various thematic maps like base map, contour map, drainage map, soil map, geomorphology map, slope map and land use/land cover map can be prepared by using SOI toposheets and satellite imageries. After analysing all maps, action plan map can be generated for sustainable land management.

Soil mapping provides important information about the characteristics and condition of the 
land. The general soil map can be used to provide an overview of the soil distribution of an area and to compare the suitability of large areas for general land uses. Soil maps and models can identify areas that are vulnerable to land degradation, prevent degradation with good planning, reduce the costs of remediation when it is necessary, and contribute to issues related to climate change (e.g., reduction of greenhouse gas emissions) and human health (e.g., soil contamination). Soil maps support sustainable land management because they provide important information about where different management practices are most appropriate. Geographic information systems and spatial statistics offer powerful tools for producing soil maps.

Land use/Land cover pattern of a region is an outcome of natural and socio-economic factors and their utilization by man in time and space. Spatial distribution of land use/land cover information and its changes is desirable for any planning, management and monitoring programmes at local, regional and national levels. This information not only provides a better understanding of land utilization aspects but also provides a vital role in the formulation of policies and programs required for developmental planning. Remote sensing and GIS technologies will indeed play a crucial role in the development of thematic layers for the sustainable development and management of vital natural resources. Hence, the present study has been taken up to develop thematic layers of Kinnerasani basin using GIS and RS for sustainable management of resources in a basin.

\section{The Study Area}

Kinnerasani basin of Telangana was selected for the study. The area of the basin is 910 sq.km. Kinnerasani River is an important tributary of the river Godavari. It is flowing through the study area. A storage reservoir is constructed on the Kinnerasani River in the Godavari basin at Yanamboli village of Palvanchamandal. The Latitude and Longitude of Kinnerasani Dam is $17^{\circ} 41^{\prime} \mathrm{N}$ and $80^{\circ} 40^{\prime} \mathrm{E}$ respectively. There are four mandals namely, Gundala, Tekulapalli, Palvancha and Burgampadu under catchment and command areas. The location map of the study area is shown in Figure 1.

\section{Physiography}

The physiography of the area is undulating having a slope of 1-6\%, varying from nearly level to steep slope. About 13 percent of the area is nearly level and 58 percent of the area is moderately sloping. The mean elevation of study area is $107 \mathrm{~m}(351 \mathrm{ft})$ above sea level.

\section{Soils}

The Kinnerasani basin consists of mainly two types of soils. Majority of the area is under Clay soils with 84 percent and clay loam soil occupies 14 percent and remaining 2 percent is under rock and water bodies. The details of different soil types are presented in Table 1 and Figure 2. The physical properties of the soils of the basin are presented in the Table 2.

The spatial variation of soil depth is the study area is shown in Figure 3. About $62 \%$ of soils are having moderately shallow to deep depth and $36 \%$ soils are very shallow (Table 3 ).

The spatial variation of soil productivity of the Kinnerasani basin has been depicted in Figure 4. 72 percent soils are moderately productive and only one percent soils are nonproductive (Table 4).

\section{Land use land cover map of Kinnerasani basin}

The LULC was prepared for the study area using IRS $\mathrm{P}_{6}$ LISS III image of June, 2013 and 
February, 2014. The information from LISS III image and toposheets were utilized for classification of land cover generation of training sets. Ground truth survey was carried out by walking around the field boundaries for two times (rabi 2014 and kharif 2013) during 2013 to 2014 using GPS.

All the field boundaries were digitized in the ERDAS IMAGINE environment. Individual crops, water bodies and settlements shape files were created in the ERDAS IMAGINE by using the AOI (Area of interest) and signature editor tools. Rest of the features was classified using toposheets and ground truth verification of doubtful areas. Major portion of the study area was covered with deciduous forest followed by crop land. The areas of different land uses of the study area are presented in Figure $5 \mathrm{a}$ and $\mathrm{b}$.
The percentage areas of different land uses of the study area we presented in Table 5 . Deciduous forest is the major land use with $64 \%$ followed by crop land with $25 \%$ of the area of Kinnerasani basin. Water bodies are occupying an area of 3\% followed by fallow land $(2 \%)$. Most of the area is under forest in the Kinnerasani basin. The area under settlement is hardly $1 \%$.

Deciduous trees play an important role in ecosystem maintenance by seasonally generating higher water yields. Deciduous trees allow more water to reach the soil and seep into streams by seasonally shedding leaves that lose water via evaporation. This increase in soil water and streamflow provides a valuable resource to the community. The higher flow can help fill storage reservoirs and mitigate water shortages during drought seasons.

Table.1 Details of soil texture map of the study area

\begin{tabular}{|l|l|l|c|}
\hline S.No. & Description & Area (ha) & Percentage \% \\
\hline $\mathbf{1}$ & Rocky and Waterbodies & 12.522 & 1.38 \\
\hline $\mathbf{2}$ & Clay Loam & 132.375 & 14.55 \\
\hline $\mathbf{3}$ & Clay & 765.156 & 84.08 \\
\hline
\end{tabular}

Table.3 Details of soil depth in the study area

\begin{tabular}{|l|l|c|c|}
\hline S.No. & \multicolumn{1}{|c|}{ Description } & $\begin{array}{c}\text { Area } \\
(\mathbf{h a})\end{array}$ & $\begin{array}{c}\text { Percentage } \\
\mathbf{\%}\end{array}$ \\
\hline $\mathbf{1}$ & Extremely shallow $(<10 \mathrm{~cm})$ & 331.67 & 36.45 \\
\hline $\mathbf{2}$ & Very shallow $(10-25 \mathrm{~cm})$ & 8.15 & 0.90 \\
\hline $\mathbf{3}$ & Shallow $(25-50 \mathrm{~cm})$ & 4.37 & 0.48 \\
\hline $\mathbf{4}$ & Moderately shallow to deep $(>50 \mathrm{~cm})$ & 565.85 & 62.18 \\
\hline
\end{tabular}

Table.4 Details of soil productivity in the study area

\begin{tabular}{|l|l|l|c|}
\hline S.No. & Description & $\begin{array}{l}\text { Area } \\
\mathbf{k m}^{\mathbf{2}}\end{array}$ & Percentage \% \\
\hline $\mathbf{1}$ & Highly Productive & 105.83 & 11.63 \\
\hline $\mathbf{2}$ & Moderately Productive & 659.32 & 72.45 \\
\hline $\mathbf{3}$ & Low Productive & 132.37 & 14.55 \\
\hline $\mathbf{4}$ & Non Productive & 12.52 & 1.38 \\
\hline
\end{tabular}


Table.5 Area (\%) under each landuse in Kinnerasani basin

\begin{tabular}{|l|l|l|}
\hline \multicolumn{1}{|c|}{ Description } & \multicolumn{1}{c|}{ Area } & \multicolumn{1}{c|}{$\%$} \\
\hline Mining & 0.12 & 0.013 \\
\hline Barren Rocky & 0.24 & 0.026 \\
\hline Scrub land & 1.66 & 0.18 \\
\hline Urban & 11.11 & 1.21 \\
\hline Crop land & 237.70 & 25.83 \\
\hline River/stream/canals & 17.71 & 1.92 \\
\hline Scrub Forest & 2.42 & 0.26 \\
\hline Fallow & 20.17 & 2.19 \\
\hline Water bodies & 29.79 & 3.24 \\
\hline Forest Plantation & 3.85 & 0.42 \\
\hline Gullied/Ravinous Land & 4.04 & 0.44 \\
\hline Rural & 5.01 & 0.54 \\
\hline Deciduous & 586.35 & 63.72 \\
\hline Total & 920.17 & 100.00 \\
\hline
\end{tabular}

Fig.1 Location map of Kinnerasani Basin, Telangana

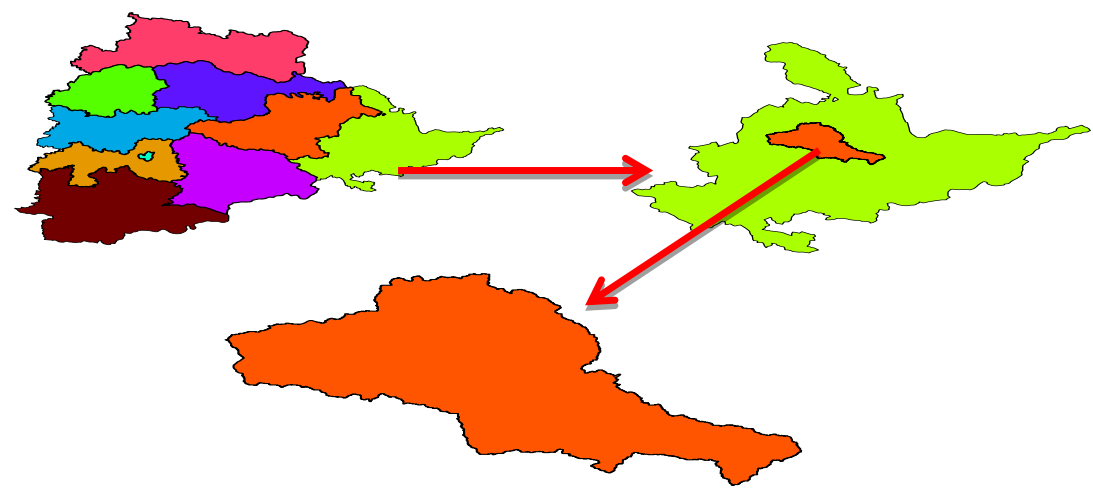

Fig.2 Soil texture map of the study area

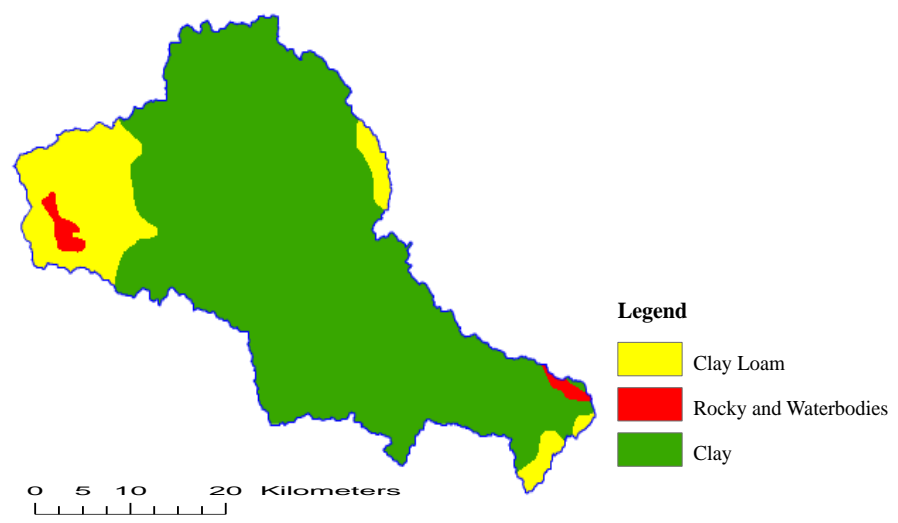


Fig.3 Spatial variation of soil depth in study area

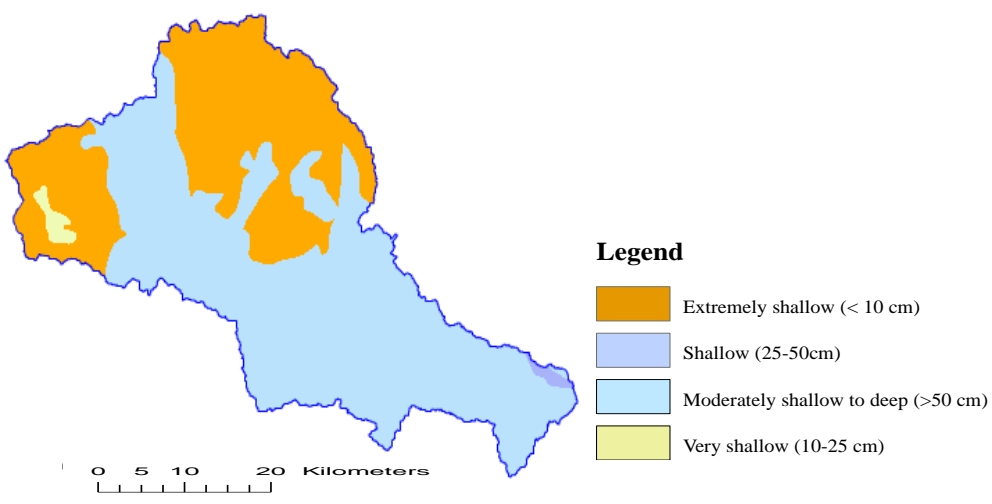

Fig.4 Spatial variation of soil productivity in the Kinnerasani basin

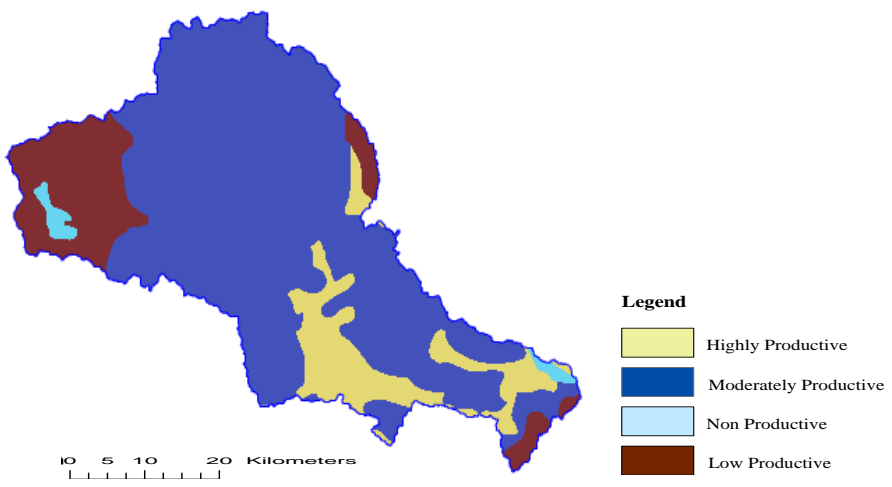

Fig.5a LULC map of Kinnerasani basin

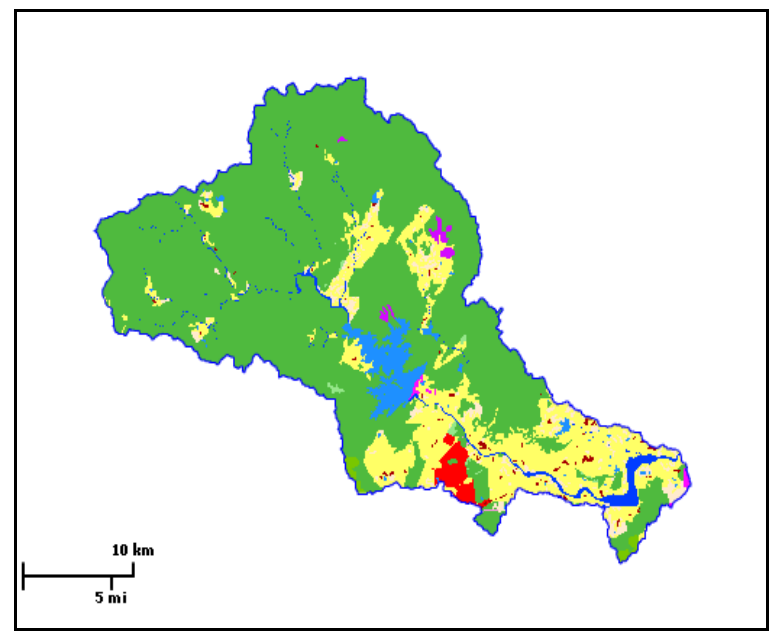


Fig.5b Area under each land use in Kinnerasani basin

\begin{tabular}{||l|l|l|}
\hline \hline & Description & Area (ha) \\
\hline \hline & Mining & 0.123 \\
\hline \hline & Barren rocky & 0.263 \\
\hline \hline & Scrub land & 1.663 \\
\hline \hline & Urban & 11.113 \\
\hline \hline & Crop land & 165.823 \\
\hline \hline & River / Stream / canals & 17.711 \\
\hline \hline & Scrub Forest & 2.415 \\
\hline \hline & Fallow & 26.479 \\
\hline \hline & Water bodies & 29.787 \\
\hline \hline & Forest Plantation & 3.85 \\
\hline \hline & Gullied / Ravinous Land & 4.043 \\
\hline \hline & Rural & 5.005 \\
\hline & Deciduous & 639.667 \\
\hline
\end{tabular}

In conclusions different thematic maps like, drainage map, basin boundary map, soil map, soil depth and productivity map, slope map and land use/land cover map were prepared by using SOI toposheets and satellite imageries for Kinnerasani basin. Crop failure due to lack of water availability is one of the major causes of distress among the farmer community. The runoff from deciduous forest can be harvested at a suitable site thereby assured supply of water can be arranged for agricultural crops. Crop lands are having moderately shallow to deep depth and highly productive. Identification of suitable site for water harvesting structure will increase the availability of water and thereby crop production.

\section{References}

Aboyade, O. 2001. Geographic information systems: application in planning and decision- making processes in
Nigera," Unpublished paper presented at the Environmental and Technological unit in the Development Policy Centre, Ibadan,

Jensen, J. R., 1996. Introductory Digital Image Processing: A Remote Sensing Perspective, Prentice Hall, Upper Saddle river, NJ, USA.

Lillesand, T. M. and R. W. 2000. Kiefer, Remote Sensing and Image Interpretation, John Wiley \& Sons, New York, NY, USA, 4th edition

Mas, J. F., 1999. Monitoring land-cover changes: a comparison of change detection techniques," International Journal of Remote Sensing, vol. 20, no. 1, pp. 139-152.

Tziztiki, J. G. M., F. M. Jean, and A. H. Everett, "Land cover mapping applications with MODIS: a literature review," International Journal of Digital Earth, vol. 5, no. 1, pp. 63-87, 2012.

\section{How to cite this article:}

Kishore Kumar, G., A Mani, G Manojkumar and Sadasiva Rao, K.. 2018. Mapping of the Matic Data of Kinnerasani Basin using GIS and RS for Management of Land Resources. Int.J.Curr.Microbiol.App.Sci. 7(12): 3189-3194. doi: https://doi.org/10.20546/ijcmas.2018.712.368 